\title{
TRADE CREATION DAN TRADE DIVERSION ANTARA INDONESIA DAN NEGARA-NEGARA ASEAN-KOREA
}

\author{
Tresna Ritaningsih ${ }^{1}$, Dedi Budiman Hakim ${ }^{2}$, Sahara $^{2}$ \\ ${ }^{1}$ Staf pada Kementerian Perdagangan dan Mahasiswa pada Program Studi Ilmu \\ Ekonomi, Fakultas Ekonomi dan Manajemen IPB \\ ${ }^{2}$ Departemen Ilmu Ekonomi, Fakultas Ekonomi dan Manajemen IPB
}

Artikel diterima Februari 2013

Artikel disetujui untuk dipublikasikan Juli 2014

\begin{abstract}
Indonesia has several free trade agreements with trading partners that aimed to eliminate tariff and non tariff trade barriers. One of the free trade agreements is ASEAN-Korea FTA. Trade agreement in goods in ASEAN-Korea FTA was agreed since 2007 and now it is entering the implementation phase. The objective of this research is to determine whether the ASEAN-Korea FTA would increase the trade flows between Indonesia and ASEAN-Korea' countries by analyzing the impact of regional integration on trade creation and trade diversion. This research is utilized balance panel data including 13 countries from 1998-2012. The empirical result shows that all Indonesia's trading sectors experienced decline because of trade diversion and trade creation does not occur. Indonesia's import trading with the non-member countries of ASEAN-Korea is 68\% lower than the existing trading.
\end{abstract} Key word: trade creation, trade diversion, free trade agreement, trade in goods

\begin{abstract}
ABSTRAK
Indonesia mempunyai beberapa perjanjian perdagangan bebas dengan negara mitra dagang dengan tujuan untuk menghilangkan hambatan tarif dan non-tarif. Salah satu perjanjian perdagangan bebas tersebut adalah ASEAN-Korea FTA. Perjanjian perdagangan barang pada ASEAN-Korea FTA telah diberlakukan sejak tahun 2007 dan sekarang memasuki fase implementasi. Tujuan dari penelitian ini adalah untuk menentukan apakah ASEAN-Korea FTA dapat meningkatkan arus perdagangan antara Indonesia dan negara-negara ASEAN-Korea dengan menganalisis dampak dari integrasi regional dalam trade creation dan trade diversion. Penelitian ini menggunakan data panel yang mencakup 13 negara dari tahun 1998-2012. Hasil empiris menunjukkan bahwa secara keseluruhan sektor perdagangan Indonesia mengalami kerugian akibat terjadinya trade diversion dan tidak terjadi trade creation. Arus perdagangan impor Indonesia dengan negara-negara non-anggota ASEAN-Korea sebesar 68\% lebih sedikit dari tingkat perdagangan yang saat ini telah dilakukan.
\end{abstract}

Kata kunci : trade creation dan trade diversion, perjanjian perdagangan bebas, perdagangan barang

* Penulis untuk korespondensi, Telp: 08128040238

Email: tresna.ritaningsih@gmail.com 


\section{PENDAHULUAN}

Dalam perdagangan internasional, sebagian besar negara di dunia melakukan perdagangan dengan negara lain melalui organisasi perdagangan internasional yang memakai sistem perdagangan multilateral, yang dikenal dengan World Trade Organization (WTO). Organisasi ini merupakan forum bagi pemerintah dalam menegosiasikan perjanjian perdagangan dengan tujuan untuk mencapai perdagangan bebas lintas global yang berdasarkan prinsip non-diskriminasi (Most Favoured Nation dan National Treatment). WTO dibentuk pada tahun 1995 setelah putaran uruguay sebagai pengganti General Agreement on Tariff and Trade (GATT). Putaran uruguay merupakan putaran terakhir dan terbesar dari putaran GATT yang dimulai dari tahun 1986 hingga 1994. Namun demikian, putaran uruguay berjalan cukup lambat dalam menyelesaikan negosiasinya. Hal ini dapat dilihat dari hasil negosiasi yang gagal untuk dicapai pada saat pertemuan para menteri di Brussels, bulan Desember 1990 (WTO 2013a). Kegagalan ini memicu negara-negara anggota untuk membentuk kawasan perdagangan bebas dengan menandatangani perjanjian perdagangan bebas secara regional maupun bilateral dengan mengadopsi aturan-aturan WTO agar hambatan perdagangan dalam bentuk tarif dan non-tarif dapat dikurangi atau dihilangkan.

Kawasan perdagangan bebas menjadi aspek unggulan dalam mengatasi masalah yang dihadapi negara-negara anggota WTO, yang dapat dilihat dari jumlah FTA yang terdaftar dalam GATT. Tahun 1990, terdapat 27 FTA yang terdaftar, dan mengalami kenaikan menjadi 575 FTA per tanggal 31 Juli 2013 yang tercatat oleh GATT/WTO. Sebanyak 379 FTA telah diberlakukan dan sisanya masih dalam tahap negosiasi (WTO 2013). Perjanjian perdagangan bebas telah diatur dalam article XXIV GATT 1994 yang menjelaskan tentang keterkaitan antara WTO dan FTA.

Kawasan perdagangan bebas atau FTA merupakan salah satu bentuk integrasi ekonomi di dunia yang akan memberikan perlakukan khusus kepada negara mitra dagangnya dan mendiskriminasikan negara mitra dagang yang tidak masuk dalam FTA. FTA dapat berupa penetapan tarif dan non tarif yang lebih rendah bahkan tidak ada sama sekali. Dengan menurunkan atau menghilangkan hambatan perdagangan diantara anggota, FTA dapat meningkatkan alokasi sumber daya didalam kawasan dan meningkatkan pendapatan untuk negara-negara anggota. Hal ini sesuai dengan yang dikemukakan oleh Salvatore (1997) bahwa perdagangan bebas akan memaksimalkan output dunia dan keuntungan bagi setiap negara yang terlibat didalamnya.

Bentuk kawasan perdagangan bebas yang telah ada diantaranya European Union (EU), the North America Free Trade Area (NAFTA), dan the Association of Southeast Asian Nations (ASEAN).

Dalam perkembangannya, hubungan kerjasama ASEAN tidak hanya dilakukan antar negara-negara anggota ASEAN, tetapi juga melibatkan negara-negara diluar ASEAN yang disebut dengan negara mitra dagang. Bentuk kerjasama yang telah disepakati diantaranya ASEAN-China Free Trade Agreement (ACFTA), ASEAN-Korea Free Trade Agreement (AKFTA), dan ASEAN-Australia-New Zealand Free Trade Agreement (AANZFTA) (Departemen Perdagangan 2010).

ASEAN-Korea FTA merupakan bentuk kerjasama dalam kerangka ASEAN Plus One setelah ACFTA. ASEAN dan Korea Selatan menandatangani the Framework Agreement on Comprehensive Economic Cooperation pada tahun 2005 dan kemudian menandatangani empat perjanjian lainnya yang membentuk instrumen hukum dalam pembentukan 
ASEAN-Korea FTA (AKFTA), salah satunya perjanjian perdagangan barang ASEAN-Korea FTA yang berlaku mulai tahun 2007 dan telah diimplementasi secara penuh pada tahun 2010. Pendirian AKFTA menciptakan kesempatan bagi 670 juta warga ASEAN dan Korea dengan PDB gabungan sebesar USD 2.9 triliun untuk lebih liberal, memfasilitasi akses pasar dan rezim investasi antar anggota AKFTA $^{1}$. Tujuan dari pembentukan AKFTA adalah untuk mewujudkan kawasan perdagangan bebas dengan menghilangkan atau mengurangi hambatan-hambatan perdagangan barang baik tarif ataupun non tarif, peningkatan akses pasar jasa, peraturan dan ketentuan investasi, sekaligus peningkatan aspek kerjasama ekonomi untuk mendorong hubungan perekonomian para pihak AKFTA dalam rangka meningkatkan kesejahteraan masyarakat ASEAN dan Korea (Kementerian Perdagangan 2013).

Dalam mewujudkan tujuan dari pembentukan AKFTA, serangkaian tahapan telah dilakukan negara-negara anggota seperti Indonesia yang mengimplementasikan penggunaan Surat Keterangan Asal atau SKA form-AK dan penghapusan tarif bea masuk. Tahapan tersebut memberikan dampak positif dan negatif terhadap perkembangan ekonomi di Indonesia. Hal ini dapat dilihat dari pertumbuhan PDB Riil Indonesia yang mengalami penurunan sebesar $0.3 \%$ dari tahun 2011 ke 2012 setelah mengalami kenaikan sebesar $0.3 \%$ dari tahun 2010 ke 2011 dengan perubahan inflasi dari 5.4\% menjadi $4.3 \%$ serta penurunan pada neraca perdagangan sebesar $7.3 \%$ pada periode yang sama tahun 2011 ke 2012 (IMF 2013).

Transaksi perdagangan antara ASEAN dengan negara mitra dagang merupakan implikasi dari kerjasama yang terjalin antara negara-negara tersebut yang diwujudkan pada persentase total

\footnotetext{
${ }^{1}$ Sumber : www.akftaasean.org diakses pada 10 Oktober 2013
}

perdagangan pada Gambar 1 sebagai bentuk kegiatan perdagangan barang kedua negara tersebut. Semakin besar volume transaksi perdagangan suatu negara, baik ekspor maupun impor, maka dapat dikatakan tingkat keterbukaan negara tersebut semakin tinggi. Terlihat bahwa persentase total perdagangan ekspor dan impor ASEAN yang terbesar di tahun 2013 adalah dengan Cina sebesar $14 \%$, yang diikuti oleh Jepang sebesar $10 \%$, Korea Selatan sebesar 5\%, Australia dan India sebesar 3\%, New Zealand sebesar $0.4 \%$ dan lainnya $65 \%$.

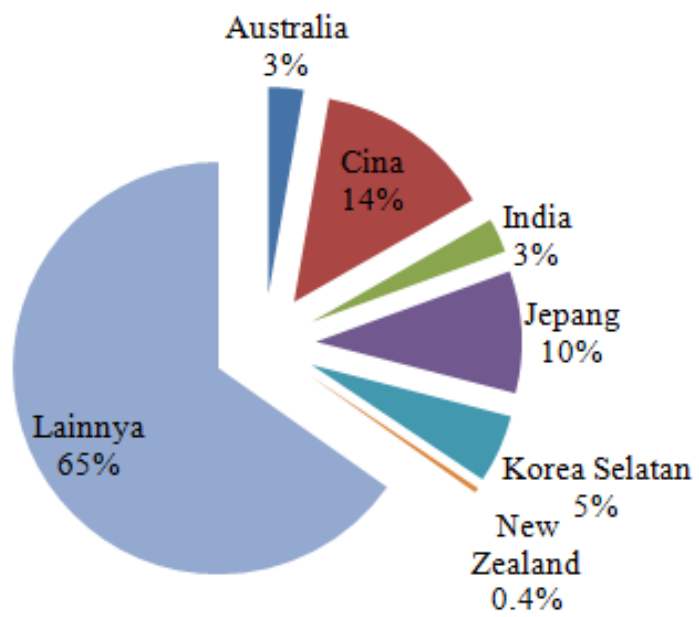

Gambar 1 Persentase Total Perdagangan ASEAN dengan Negara Mitra Dagang (\%)

Sumber : ASEANStats, 2013

Persentase yang ditampilkan pada Gambar 1 mewakili perkembangan perdagangan ASEAN dengan negara mitra dagang dimana Korea Selatan menjadi negara mitra dagang ketiga setelah Cina dan Jepang. Hampir setiap tahun perdagangan ASEAN dan Korea mengalami peningkatan dimana total perdagangannya mencapai US\$ 134974.6 juta. Hal ini yang mendasari pemilihan ASEAN-Korea sebagai kawasan dalam penelitian ini.

Transaksi

perdagangan ASEAN-Korea terjalin cukup intens, dimana ASEAN merupakan mitra dagang terbesar kedua Korea Selatan setelah Cina dengan menyumbang $12 \%$ dari total 
perdagangan Korea (USD 1080 miliar) ${ }^{2}$ dan Korea Selatan merupakan mitra dagang keenam ASEAN setelah intra-ASEAN, Cina, Jepang, EU-28, dan Amerika Serikat. Tahun 2012, total perdagangan ASEAN terhadap Korea Selatan sebesar US\$ 130.9 miliar, mengalami kenaikan dari tahun sebelumnya. Sedangkan nilai ekspor dan impornya sebesar US\$ 54.9 miliar dan US\$ 76 miliar serta total perdagangannya menyumbangkan 5.3\% di tahun 2012 (ASEANstats 2013).

Dilihat dari sisi negara anggota ASEAN, Indonesia merupakan salah satu negara pelopor dibentuknya ASEAN dan negara berkembang yang sudah melakukan beberapa kerjasama dengan negara lain baik secara bilateral maupun regional/ multilateral. Total perdagangan Indonesia di ASEAN mencapai US\$ 380.9 miliar di tahun 2011 dan US\$ 381.7 miliar di tahun 2012 dengan perubahan dari tahun ke tahun sebesar $0.2 \%$ (ASEANstats 2013). Hal tersebut menunjukkan adanya peningkatan jumlah total perdagangan yang berdampak pada perekonomian di Indonesia, yaitu meningkatnya kinerja perdagangan ekspor dan impor. Sedangkan total perdagangan Indonesia dengan Korea Selatan sebesar US\$29.39 miliar di tahun 2011 dan US\$ 27.02 miliar di tahun $2012^{3}$. Data tersebut mengindikasikan terjadinya penurunan volume perdagangan di kedua negara.

Berdasarkan data yang diperoleh dari Trademap (2013), ada dua jenis komoditi ekspor utama Indonesia ke ASEAN dan Korea Selatan yang sama yaitu bahan bakar mineral dengan nilai ekspor tertinggi yang masing-masing bernilai US\$ 14093 juta dan US\$ 10991 juta dan mesin/ peralatan listrik yang masing-masing bernilai US\$ 3662 juta dan US\$ 382 juta di tahun 2012. Untuk komoditi-komoditi impor utama dari ASEAN dan Korea

\footnotetext{
${ }^{2}$ Sumber : www.aseankorea.org diakses 10 Oktober 2013

${ }^{3}$ Sumber : www.trademap.org diakses 10 Oktober 2013
}

Selatan yang masuk dalam pasar Indonesia dengan jenis yang sama diantaranya bahan bakar mineral, mesin-mesin/pesawat mekanik, mesin/peralatan listrik, plastik dan barang dari plastik, besi dan baja, serta benda-benda dari besi dan baja.

Total nilai komoditi ekspor utama Indonesia ke ASEAN (Association South East Asian Nation) dan Korea Selatan mengalami penurunan pada tahun $2011 \mathrm{ke}$ 2012 dengan selisih US\$ 267 juta dan US\$ 1339 juta, sementara total nilai komoditi impor utama dari ASEAN mengalami peningkatan pada tahun 2011 ke 2012 sebesar US\$ 2522 juta sedangkan total nilai komoditi impor utama dari Korea Selatan mengalami penurunan dari tahun 2011 ke 2012 sebesar US\$ 1029 juta (Trademap 2013).

Berdasarkan data tersebut, terlihat bahwa terjadi perbedaan jumlah impor dari ASEAN dan Korea Selatan ke pasar Indonesia yang beredar dan dikonsumsi oleh masyarakat Indonesia. Hal ini dapat mempengaruhi perkembangan sektor perdagangan dan memicu terjadinya trade creation dan/atau trade diversion antara Indonesia dengan negara-negara ASEAN-Korea. Menurut Viner (1950), trade creation (penciptaan perdagangan) terjadi ketika suatu negara mengurangi atau menghilangkan tarifnya pada impor dari negara-negara anggota FTA dan jumlah impor dari negara-negara tersebut meningkat. Peningkatan ini memberikan manfaat berupa kesejahteraan yang lebih baik di suatu negara. Trade diversion (pengalihan perdagangan) terjadi ketika pembentukan FTA mendorong suatu negara, yang biasanya memberikan biaya rendah kepada negara di dunia, untuk mengganti pemasoknya kepada negara-negara anggota yang kurang kompetitif (kurang efisien). Pengalihan ini akan menghasilkan penambahan biaya dan dapat mengurangi pendapatan suatu negara. 
Untuk mengantisipasi banyaknya produk impor yang masuk ke pasar Indonesia, pemerintah telah membuat suatu kebijakan yang berkenaan dengan tarif bea masuk dalam ASEAN-Korea FTA yang tertuang dalam peraturan menteri keuangan (PMK) No. 118/PMK.011/2012 tentang penetapan tarif bea masuk dalam rangka ASEAN-Korea Free Trade Area (FTA), peraturan Menteri Perdagangan (Permendag) No.59/M-DAG/PER/12/ 2010 tentang ketentuan penerbitan SKA (Surat Keterangan Asal) untuk barang ekspor Indonesia, dan UU No. 7 Tahun 2014 tentang Perdagangan.

Berdasarkan latar belakang dan identifikasi serta rumusan masalah yang telah diuraikan diatas, maka tujuan dari penelitian ini adalah menganalisis terjadinya trade creation dan/ atau trade diversion di sektor perdagangan Indonesia terutama impor dalam ASEAN-Korea FTA.

\section{TINJAUAN PUSTAKA}

Beberapa tinjauan pustaka/ penelitian terdahulu yang menjadi dasar dalam melakukan penelitian ini, diantaranya penelitian yang dilakukan oleh Zidi \& Dhifallah (2013) dengan melakukan analisis dampak yang akan terjadi pada arus perdagangan di Tunisia-EU FTA berupa terjadinya trade creation atau trade diversion. Gravity model digunakan dalam menguji variable-variabel yang dipakai dengan rentang waktu dari tahun 1986-2010 dengan melibatkan 41 negara. Hasil yang didapat adalah tidak terjadi trade creation antara Tunisia-EU dan terjadi trade diversion pada ekspor yang dilakukan oleh Tunisia.

Menurut penelitian yang dilakukan Agbodji (2008), bentuk evaluasi terhadap trade creation dan trade diversion dapat dilakukan dengan menganalisis dampak individual economic dan monetary union pada intra-UEMOA (Economic and Monetary Union of West Africa). Ditunjukkan bahwa anggota dari common monetary area dan implementasi economic reform mempunyai dampak signifikan pada trade diversion di ekspor dan impor, dan tidak terjadi trade creation dengan menggunakan gravity model.

Penelitian lain yang juga menganalisis dampak dari FTA dilakukan oleh Jin et al (2006) yaitu pada China, Japan, South Korea FTA, dimana efek tersebut berdampak besar dalam menciptakan trade diversion antar negara anggota. Berdasarkan sumber endowment yang dimiliki masing-masing negara, dapat meningkatkan volume perdagangan melalui inter-industry trade berdasarkan prinsip comparative advantage dan analisisnya menggunakan model GTAP.

$$
\text { Penelitian Clausing (2001) }
$$

dilakukan dengan tujuan untuk mengetahui dampak dari liberalisasi tarif di CUSFTA dan menganalisis hasil dari peningkatan perdagangan antara Kanada dan Amerika Serikat sebagai hasil dari liberalisasi tarif berupa trade creation atau trade diversion. Ditunjukkan bahwa terjadi peningkatan impor yang cukup signifikan dari Kanada dalam pertumbuhan impor Amerika Serikat dibandingkan dari sisa dunia (rest of the world). Akan terjadi trade diversion jika perdagangan barang dengan negara non-partner cukup liberal daripada perdagangan barang yang kurang liberal atau tidak liberal sama sekali.

Roberts (2004) meneliti tentang arus perdagangan yang terjadi pada ASEAN-China FTA dengan menganalisis PDB, PDB per kapita masing-masing negara anggota, perbedaan PDB per kapita, dan biaya jarak perdagangan antar pasangan negara sebagai variabel bebas. Dengan judul penelitian A Gravity Study of the Proposed China-ASEAN Free Trade Area, peneliti mempunyai tujuan untuk menguji kesesuaian model gravity untuk Regional Trade Area (RTA) yang 
diusulkan, dan mencari tahu dari implikasi kebijakan yang ada terhadap RTA yang diusulkan dan Multilateral Trade System. Hasil yang didapat menunjukkan bahwa variable biaya jarak perdagangan mempunyai efek yang signifikan terhadap arus perdagangan dan nilai koefisien dari perbedaan PDB per kapita yang tidak signifikan mengartikan bahwa ASEAN-China FTA tidak memiliki pola permintaan yang sama dan sektor
Laos, Korea Selatan dan empat negara pengimpor utama Indonesia di tahun 2012 yaitu Cina, Jepang, Amerika Serikat, Australia. Periode penelitian dimulai dari tahun 1998 selain karena alasan ketersediaan data, dimaksudkan pula untuk melihat dampak integrasi regional sebelum kerja sama ASEAN-Korea diberlakukan.

Jenis dan sumber data untuk bahan penelitian secara ringkas disajikan dalam Tabel 1.

Tabel 1 Jenis dan Sumber Data dalam Penelitian

\begin{tabular}{lll}
\hline No. & Data & Sumber \\
\hline 1. & Impor (Juta USS) & WITS \\
2. & PDB Riil Per Kapita (Juta USS) & IFS dan World Bank \\
3. & Nilai Tukar Riil & WDI dan IFS \\
4. & Jarak & CEPII \\
\hline
\end{tabular}

manufaktur lebih memproduksi barang yang berbeda untuk setiap pasar. Hal ini membawa negara anggota ASEAN-China untuk memetakan kebijakan dan strateginya dalam mengkonvergensi tingkat pendapatan dengan manfaat maksimum sebagai harapan dari usulan FTA.

\section{METODE PENELITIAN}

Data yang digunakan dalam penelitian ini merupakan data sekunder yang berasal dari berbagai sumber, yaitu ASEANStat, World Integrated Trade Solution (WITS), World Bank (World Development Indicators, WDI 2012), International Monetary Fund (International Financial Statistics 2012), Trademap, CEPII, Kementerian Perdagangan dan sumber-sumber lainnya. Data yang dikumpulkan tersebut merupakan data panel dengan time series tahunan 1998 - 2012 dan cross section tiga belas negara yang terdiri dari sepuluh negara anggota ASEAN-Korea, yaitu Malaysia, Singapura, Filipina, Thailand, Brunei Darusalam, Kamboja, Vietnam,
Metode analisis yang digunakan dalam penelitian menggunakan analisis data panel dengan model gravity. Analisis ekonometrika dengan regresi data panel gravitasi digunakan untuk melihat keterkaitan antara arus perdagangan dan perekonomian negara.

Dalam gravity model sederhana, perdagangan antara negara $i \mathrm{dan}$ negara $\mathrm{j}$ bersifat proporsional terhadap ukuran ekonomi dan berbanding terbalik dengan jarak, yang menjadi proxy bagi biaya transportasi diantara kedua negara. Secara umum dapat digambarkan seperti berikut:

$$
X_{i j}=A \frac{Y_{i} Y_{j}}{D_{i j}}
$$

dimana $X_{i j}$ adalah arus perdagangan antara negara i dan negara $j$. $Y_{i}$ adalah PDB untuk negara $\mathrm{i}$ dan $\mathrm{Y}_{\mathrm{j}}$ untuk negara $\mathrm{j}$. $\mathrm{D}_{\mathrm{ij}}$ sebagai jarak geografis antara kedua negara, yang sering diukur menggunakan kalkulasi "great circle".

Untuk melihat dampak dari kebijakan ekonomi dan beberapa masalah termasuk budaya, sejarah, faktor geografis pada perdagangan, para ekonom menggunakan bermacam-macam variabel 
dan indikator dalam gravity model, seperti hubungan kolonial, mata uang bersama, batas-batas, dan bahasa bersama. Diantara hal-hal tersebut, yang menjadi kunci utama dalam menganalisis dampak dari kebijakan perdagangan yaitu menggunakan variabel dummy seperti FTA $_{\mathrm{ij}}$, untuk mengindikasikan keberadaan perjanjian perdagangan regional antara negara i dan negara $\mathrm{j}$. Variabel dummy ini dapat pula mengestimasi efek trade creation dan trade diversion dan memberikan kontribusi penting dalam perjanjian tersebut.

Model yang digunakan berdasarkan asumsi bahwa impor negara i dari negara $\mathrm{j}$ tergantung pada variabel gravity seperti PDB, PDB per kapita dan Jarak. Spesifikasi dasar dari persamaan gravity meliputi faktor-faktor dari negara pengimpor misal PDB dan PDB per kapita, faktor pemasok dari negara pengekspor misal PDB dan PDB per kapita, dan juga jarak geografis sebagai proxy untuk biaya transportasi.

Persamaan gravity sederhana secara umum dijelaskan sebagai berikut:

$\ln \mathrm{M}_{\mathrm{ijt}}=\beta_{0}+\beta_{1} \ln G D P_{i t}+\beta_{2} \ln G D P_{j t}+\beta_{3} \ln$ $U_{i j t}$

dimana $\mathrm{M}_{\mathrm{ij}}$ adalah impor perdagangan antara negara $\mathrm{i}$ dan negara $\mathrm{j}$. GDP $_{\text {it }}$ adalah PDB untuk negara $i$ dan $\mathrm{GDP}_{\mathrm{jt}}$ untuk negara $\mathrm{j}$ dalam tahun ke-t. $\mathrm{D}_{\mathrm{ij}}$ sebagai jarak geografis antara kedua negara.

Dalam gravity model dari perdagangan bilateral, diperlukan pengujian asumsi pada data panel untuk mengetahui estimasi bias. Jika model yang terpilih berdasarkan uji Hausman adalah REM maka estimasi dari model diasumsikan best linier unbiased estimator (BLUE) dan tidak perlu dilakukan pengujian terhadap tiga asumsi utama model BLUE (non-multicolinierity, homoskedasticity, dan nonautocorelation). Hal ini dikarenakan dua alasan, yaitu: (i) sifat data panel adalah bebas dari gejala multikolinieritas; dan (ii) REM adalah model generalized least square $(G L S)$, dan estimasi dengan menggunakan GLS secara otomatis sudah terbebas dari gejala autokorelasi, bahkan terbebas dari gejala heteroskedastisitas yang disebabkan variansi sisaannya konstan (Gujarati 2004).

Jika model yang terpilih adalah FEM maka perlu dilakukan pengujian terhadap asumsi sisaan, sebagai berikut:

\section{a. Uji Heteroskedastisitas}

Asumsi pertama yang harus dipenuhi dalam persamaan regresi adalah bahwa taksiran parameter dalam model regresi bersifat BLUE maka varian $\left(\mathrm{u}_{\mathrm{i}}\right)$ harus sama dengan $\sigma^{2}$ (konstan), atau semua residual atau error memiliki varian yang sama. Kondisi itu disebut dengan homoskedastisitas. Apabila varian tidak konstan atau berubah-ubah disebut dengan heteroskedastisitas. Untuk mendeteksi adanya heteroskedastisitas dapat menggunakan metode Breusch-Pagan Test. Jika nilai probabilitas (Prob>chi2) lebih besar dari a (0.05) maka dapat disimpulkan bahwa tidak terjadi heteroskedastisitas. Hipotesis dari uji heteroskedastisitas:

$\mathrm{H}_{0}$ : Homoskedastisitas

$\mathrm{H}_{1}$ : Heteroskedastisitas

Hipotesis nol akan ditolak bila (Prob $>$ chi2) $<\alpha$ atau nilai chi $^{2}>$ nilai kritis t-tabel.

\section{b. Uji Autokorelasi}

Autokorelasi adalah korelasi yang terjadi antar observasi dalam satu peubah atau korelasi antara error masa yang lalu dengan error pada saat ini. Uji autokorelasi yang dilakukan tergantung pada jenis data dan sifat model yang digunakan. Autokorelasi dapat memengaruhi efisiensi dari penduganya. Untuk melakukan uji autokorelasi pada data panel dapat menggunakan Wooldridge test. Jika nilai probabilitas (Prob>F) lebih besar dari $\alpha$ 
(0.05) maka dapat disimpulkan bahwa tidak terjadi autokorelasi. Hipotesis dari uji autokorelasi:

$\mathrm{H}_{0}$ : tidak ada autokorelasi

$\mathrm{H}_{1}$ : ada autokorelasi

Hipotesis nol akan ditolak bila $($ Prob $>F)<$ $\alpha$.

Pengujian parameter model bertujuan untuk mengetahui kelayakan model dan apakah koefisien yang diestimasi telah sesuai dengan teori atau hipotesis. Pengujian parameter meliputi koefisien determinasi $\left(\mathrm{R}^{2}\right)$, uji koefisien regresi secara menyeluruh (F-test/uji $\mathrm{F})$ dan uji koefisien regresi secara parsial (uji t).

\section{a. Uji-F}

Uji-F digunakan untuk melakukan uji hipotesis koefisien (slope) regresi atau parameter model secara menyeluruh/ bersamaan. Kriteria pengujiannya adalah jika nilai nilai $\mathrm{F}$ observasi $>\mathrm{F}$ tabel atau nilai probabilitas $F$-statistic $<$ taraf nyata $(\alpha)$, maka keputusan menolak $\mathrm{H}_{0}$ signifikan. Dengan menolak $\mathrm{H}_{0}$ berarti minimal ada satu peubah bebas yang berpengaruh nyata terhadap peubah tak bebas.

\section{b. Uji-t}

Setelah melakukan uji koefisien regresi secara keseluruhan, maka langkah selanjutnya adalah menguji koefisien regresi secara parsial menggunakan uji-t. Hipotesis pada uji-t adalah : $\mathrm{H}_{0}: \beta_{\mathrm{i}}=0 \mathrm{Vs}$ $\mathrm{H}_{1}: \beta_{\mathrm{i}} \neq 0$. Keputusan dalam pengujian ini dilakukan dengan membandingkan nilai t-hitung dengan t-tabel atau dengan melihat nilai probabilitas dari t-hitung. Jika nilai t-hitung $>$ t-tabel atau jika nilai probabilitas $\mathrm{t}<\alpha=0.05$ maka keputusan menolak $\mathrm{H}_{0}$. Kesimpulannya adalah peubah bebas secara parsial signifikan mempengaruhi peubah tak bebas.

c. Koefisien Determinasi $\left(\mathbf{R}^{2}\right)$
Koefisien determinasi (Goodness of Fit) merupakan suatu ukuran yang penting dalam regresi, karena dapat menginformasikan baik atau tidaknya model regresi hasil estimasi. Nilai $\mathrm{R}^{2}$ mencerminkan seberapa besar variasi dari peubah bebas $Y$ dapat diterangkan oleh peubah tak bebas $X$. Jika $\mathrm{R}^{2}=0$, maka variasi dari $Y$ tidak dapat diterangkan oleh $X$ sama sekali, namun jika $\mathrm{R}^{2}=1$ maka variasi dari $Y$ secara keseluruhan dapat diterangkan oleh $X$. Semakin tinggi nilai koefisien determinasi maka model akan semakin baik.

Untuk itu, spesifikasi model yang digunakan dalam penelitian mengacu pada gravity model yang digunakan oleh Zidi \& Dhifallah (2013) serta Agbodji (2008). Model Zidi \& Dhifallah (2013) mendefinisikan impor bilateral sebagai fungsi dari pendapatan domestik bruto, pendapatan per kapita, jarak, nilai tukar riil, dummy perbatasan, dummy persamaan bahasa, dan dummy persamaan kolonial serta dummy efek integrasi. Model tersebut digunakan dalam penelitian "Trade Creation and Trade Diversion between Tunisia and EU: Analysis by Gravity Model" untuk negara Tunisia dan negara-negara anggota EU periode 1986 - 2010. Sementara itu, model Agbodji (2008) yang digunakan dalam penelitiannya yang berjudul "The Impact of Subregional Integration on Bilateral Trade: The Case of UEMOA" mendefinisikan impor bilateral sebagai fungsi dari pendapatan domestik bruto, populasi, jarak, nilai tukar riil, dummy perbatasan, dummy kepulauan, dummy indeks infrastruktur, dummy keanggotaan UEMOA, dummy keanggotaan ECOWAS dan dummy keanggotaan ASEAN untuk 65 negara selama 19 tahun.

Adapun model yang digunakan dalam penelitian ini adalah 


$$
\begin{aligned}
\operatorname{lnIM}_{i j t}=\alpha_{0}+ & \alpha_{1} \operatorname{lnPDBK}_{i t}+\alpha_{2}{\ln P D B K_{j t}} \\
& +\alpha_{3} \text { lnJarak }_{i j}+\alpha_{4} \text { lnKurs }_{i j t} \\
& +\alpha_{5} \text { Bahasa }_{i j}+\alpha_{6} \text { IM }_{I N A-A K} \\
& +\alpha_{7} \text { IM }_{I N A-I M U} \\
& +\alpha_{8} \text { DEebijakan }_{t}+\varepsilon_{i j t}
\end{aligned}
$$

Keterangan:

- i : Indonesia

- j : delapan negara anggota ASEAN + Korea Selatan dan empat negara asal impor utama Indonesia

- $\operatorname{lnI} M_{i j t}$ : nilai impor bilateral dari negara j ke negara i tahun ke-t (juta US\$), dalam $\log$ natural $(\ln )$;

- $\ln P D B K_{i t}$ : Pendapatan Domestik Bruto (PDB) riil per kapita negara i tahun ke-t (juta US\$), dalam log natural (ln);

- $\ln P D B K_{j t}$ : Pendapatan Domestik Bruto (PDB) riil per kapita negara $j$ tahun ke-t (juta US\$), dalam log natural (ln);

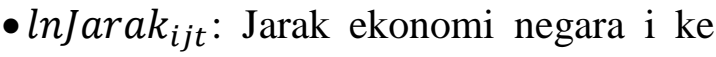
negara j pada tahun ke-t, dalam log natural (ln). Penghitungan jarak ekonomi adalah sebagai berikut:

$\operatorname{Jarak}_{i j t}=$

$\left(\frac{\text { Jarak geografis }}{P D B_{j} / \sum P D B_{\text {seluruh negara yang dianalisis }}}\right)_{t}$

- lnKurs $_{i j t}$ : Nilai tukar riil negara $\mathrm{j}$ terhadap negara i pada tahun ke-t, dalam $\log$ natural (ln). Penghitungan nilai tukar riil adalah sebagai berikut:

Kurs $_{i j t}=\left(\frac{I H K \text { negara } j}{I H K \text { negarai }}\right)_{t} X\left(\frac{\text { Nilai tukar nominal negara } i / \$}{\text { Nilai tukar nominal negara } j / \$}\right)_{t}$

- Bahasa $_{i j}$ : Variabel dummy untuk bahasa, bernilai 1 jika keduanya menggunakan bahasa yang sama, dan bernilai 0 jika keduanya tidak menggunakan bahasa yang sama

- IM $M_{I N A-A K}$ : Variabel dummy untuk mengindikasikan efek dari trade creation. Variabel dummy akan bernilai 1 jika negara pengimpor adalah Indonesia dan negara pengekspor $\mathrm{j}$ adalah salah satu negara anggota ASEAN-Korea, dan bernilai 0 jika sebaliknya

- IM INA-IMU $_{\text {: Variabel dummy untuk }}$ mengindikasikan efek trade diversion impor. Variabel dummy akan bernilai 1 jika negara pengimpor adalah Indonesia dan negara pengekspor $\mathrm{j}$ adalah Cina, Jepang, Australia atau Amerika Serikat, dan bernilai 0 jika sebaliknya Variabel dummy yang mengindikasikan efek trade creation dan trade diversion dapat disimpulkan sebagai berikut:

- Terjadi efek trade creation jika $\alpha_{6}$ dan $\alpha_{7}$ bertanda positif;

- Terjadi efek trade diversion jika $\alpha_{6}$ bertanda positif dan $\alpha_{7}$ bertanda negatif.

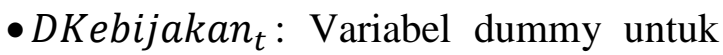
mengindikasikan tahun pemberlakukan FTA, bernilai 1 jika tahun ke-t setelah tahun 2007, dan bernilai 0 jika tahun ke-t sebelum tahun 2007

- $\alpha_{0}$ : Konstanta / intersep

- $\alpha_{1}, \alpha_{2}, \alpha_{3}, \alpha_{4}, \alpha_{5}, \alpha_{6}, \alpha_{7}, \alpha_{8}$ : Parameter yang diestimasi

- $\varepsilon_{i j t}$ : Error term

Keputusan untuk memilih model yang digunakan dalam analisis data panel didasarkan pada uji Hausman. Uji Hausman dilakukan untuk memilih apakah model yang digunakan Fixed Effect atau Random Effect (Firdaus 2011). Digunakan model Fixed Effect apabila statistik uji yang dihasilkan tolak $\mathrm{H}_{0}$ dan menggunakan Random Effect apabila tidak tolak $\mathrm{H}_{0}$.

\section{HASIL DAN PEMBAHASAN}

\section{Aliran Perdagangan Impor Indonesia dari ASEAN-Korea dan Negara Asal Impor Utama}

Indonesia sebagai negara yang tergabung dalam suatu kawasan perdagangan bebas telah melakukan perdagangan impor dari negara anggota maupun dari negara non anggota. ASEAN-Korea FTA merupakan salah satu kawasan perdagangan bebas yang diikuti oleh Indonesia dan telah menandatangani perjanjian perdagangan barang yang telah 
diberlakukan pada tahun 2007. nuklir, dan bahan kimia organik. Perdagangan impor Indonesia dari Sementara impor yang berasal dari Korea negara-negara ASEAN-Korea telah dilakukan jauh sebelum FTA dilakukan hingga FTA terbentuk. Adapun nilai perdagangan impor Indonesia sebelum dan sesudah perjanjian perdagangan barang ASEAN-Korea FTA diberlakukan ditunjukkan pada Gambar 2.

Selatan sebesar US\$ 11970.37 juta dan Malaysia sebesar US\$12 243.57 juta pada tahun yang sama. Nilai impor dari Malaysia juga mengalami peningkatan yang cukup signifikan. Impor yang terjadi cenderung meningkat karena kebutuhan yang diperlukan oleh Indonesia terutama

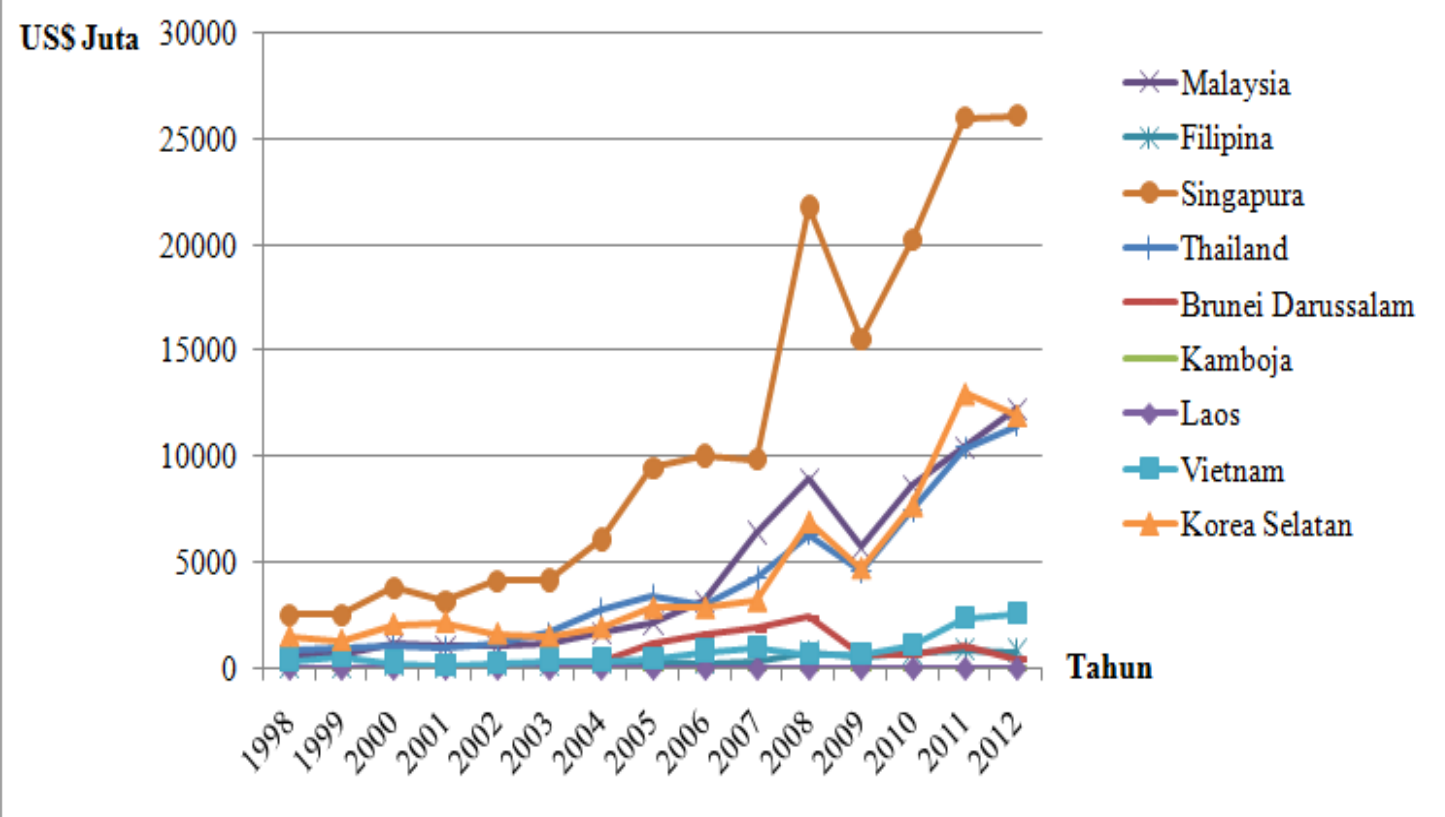

Gambar 2 Nilai Impor Indonesia dari Negara-negara ASEAN-Korea (US\$ Juta) Sumber : WITS, 2013

Berdasarkan pada Gambar 2 terlihat bahwa perdagangan impor Indonesia yang berasal dari ASEAN-Korea didominasi oleh Singapura, Korea Selatan, dan Malaysia. Impor terbesar Indonesia berasal dari Singapura dari tahun 1998 hingga 2012 dengan nilai impor pada tahun 2012 sebesar US\$ 26087.26 juta. Nilai impor yang berasal dari Singapura terus mengalami peningkatan dari tahun ke tahun. Hal ini terjadi karena Singapura merupakan pusat perdagangan dan keuangan serta tempat transit keluar masuknya barang-barang yang beredar untuk kawasan Asia Tenggara. Komoditi yang diimpor dari Singapura diantaranya bahan bakar mineral, elektronik dan peralatan elektronik, plastik, reaktor komoditi yang digunakan sebagai bahan dasar produksi seperti bahan bakar mineral, elektronik dan peralatan elektronik, plastik, reaktor nuklir, dan bahan kimia organik. Impor dari Korea Selatan mengalami penurunan dari tahun 2011 ke 2012, sebaliknya impor dari Singapura dan Malaysia mengalami peningkatan. Hal ini terjadi karena adanya pengalihan impor ke negara-negara lain seperti Australia, Jepang dan Amerika Serikat. Adapun komoditi yang diimpor dari Korea diantaranya bahan bakar mineral, besi dan baja, reaktor nuklir, elektronik dan peralatan elektronik, dan plastik. Terlihat bahwa komoditi yang diimpor dari Singapura, Malaysia dan Korea Selatan merupakan jenis yang sama. 
Hal ini dapat terjadi karena komoditi yang diperlukan oleh Indonesia saling dilengkapi oleh masing-masing negara.

Kemudian, impor terendah berasal dari Laos, Filipina dan Brunei Darussalam dengan nilai impor masing-masing sebesar US\$ 3.30 juta, US\$ 799.71 juta, dan US\$ 419.79 juta pada tahun 2012. Laos merupakan negara eksportir dengan nilai ekspor rata-rata dibawah US\$ 1 juta per tahunnya. Sementara nilai impor dari Filipina mempunyai rata-rata sebesar US\$ 365 juta dan nilai impor dari Brunei Darussalam sebesar US\$ 691 juta. Peningkatan nilai impor yang berasal dari ASEAN-Korea terjadi sejak FTA belum diberlakukan hingga FTA diberlakukan. Hal ini mengindikasikan bahwa pembentukan dan pemberlakuan ASEAN-Korea FTA mempengaruhi peningkatan nilai impor Indonesia.

Berkenaan dengan impor, negara-negara anggota menyepakati untuk menghapus tarif impor yang masuk ke negara-negaranya termasuk Indonesia. Penghapusan tarif tersebut terbagi dalam beberapa kategori yaitu normal track dan sensitive list. Normal track merupakan kategori untuk produk yang dipercepat penurunan/ penghapusan tarif bea masuknya. Korea Selatan melakukan penghapusan $70 \%$ pos tarif saat perjanjian efektif berlaku yaitu tahun 2007, paling sedikit $95 \%$ pos tarifnya menjadi $0 \%$ pada tahun 2008 dan seluruh pos tarif pada tahun 2010. Indonesia dan ASEAN-6 juga melakukan hal yang sama, yaitu melakukan penurunan $50 \%$ pos tarif menjadi $0-5 \%$ sejak perjanjian efektif berlaku, minimal $90 \%$ tarif paling lambat pada tahun 2009, dan menghapus seluruh pos tarif paling lambat tahun 2010 dengan fleksibilitas maksimum $5 \%$ pos tarif dan tenggat waktu tarif menjadi 0\% dapat diundur paling lambat tahun 2012. Sementara sensitive list adalah kategori untuk produk yang dianggap sensitif dan akan diturunkan tarif bea masuknya dengan pola yang lebih lambat dari produk dalam kategori normal track. Batas maksimum jumlah pos tarif dalam sensitive track ASEAN-6 dan Korea adalah $10 \%$ dari total pos tarif (total HS 6 digit $=5225$ pos tarif).

Selain negara-negara yang berasal dari ASEAN-Korea, terdapat pula empat negara asal impor utama Indonesia yang dipakai dalam penelitian ini dengan gambaran nilai perdagangan impor seperti pada Gambar 3. Gambar 3 menunjukkan bahwa tahun 2012 negara asal impor terbesar dari Cina dengan nilai US\$ 29 387.07 juta, disusul Jepang sebesar US\$ 22 767.83 juta, Amerika Serikat sebesar US\$ 11614.23 juta, dan Australia sebesar US\$ 5297.65 juta pada tahun 2012 . 


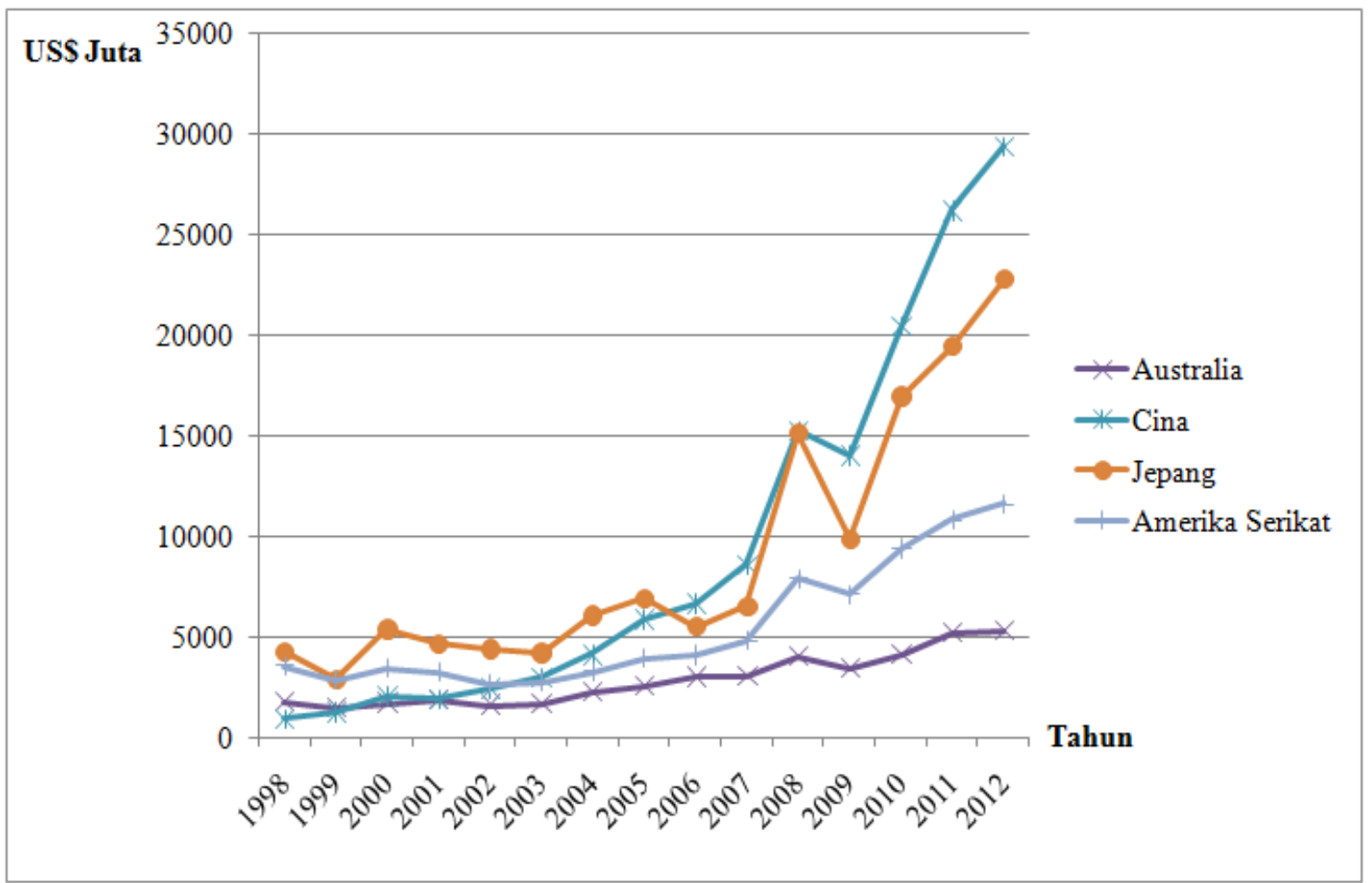

Gambar 3 Nilai Impor Indonesia dari Empat Negara Asal Impor Utama (US\$Juta) Sumber : WITS, 2013

Cina menjadi negara asal impor utama terbesar Indonesia karena harga yang diberikan relatif lebih murah dibandingkan dengan negara lain. Nilai impor yang berasal dari Cina meningkat cukup signifikan dari tahun 1998 hingga 2012 bila dibandingkan dengan Jepang, Australia, dan Amerika Serikat. Adapun komoditi yang diimpor dari Cina yaitu reaktor nuklir, elektronik dan peralatan elektronik, besi dan baja, bagian dari besi dan baja, dan bahan kimia organik. Hal yang sama juga terjadi pada impor yang berasal dari Jepang yang juga mengalami peningkatan mulai tahun 2009 hingga 2012 dimana Jepang menjadi negara pengekspor Indonesia yang terbesar di tahun 1998-2005. Peningkatan impor yang berasal dari Jepang disebabkan oleh adanya penurunan tarif yang telah disepakati oleh kedua negara melalui Indonesia-Japan Economic Partnership Agreement (IJEPA) yang telah memasuki masa implementasi. Sementara, impor yang berasal dari Amerika Serikat dan
Australia juga mengalami peningkatan tetapi tidak setinggi impor dari Cina dan Jepang. Hal ini dikarenakan persaingan harga yang terjadi di dalam pasar Indonesia. Secara umum, perdagangan impor dari Australia, Cina, Jepang dan Amerika Serikat mempunyai tren yang semakin meningkat dari tahun 1998 hingga 2012.

Berdasarkan Gambar 2 dan 3, pada tahun 2008 ke 2009 semua nilai impor yang berasal dari ASEAN-Korea maupun negara-negara pengimpor utama Indonesia mengalami penurunan yang cukup drastis. Hal ini dapat dilihat dari tren perdagangan dari masing-masing negara. Penurunan yang sangat drastis terlihat pada nilai impor yang berasal dari Singapura, Malaysia, Korea Selatan, dan Jepang. Kemungkinan penyebab dari penurunan nilai impor tersebut dikarenakan krisis ekonomi dan keuangan yang dihadapi Amerika Serikat pada tahun tersebut. Akan tetapi nilai impor dari negara-negara 
tersebut meningkat kembali pada tahun 2009 hingga 2012.

\section{Analisis Trade Creation dan Trade Diversion antara Indonesia dengan Negara - negara ASEAN-Korea}

Dalam penelitian ini, untuk memperoleh model yang cocok maka dilakukan uji kelayakan dan kecocokan model (goodness of fit). Untuk memperoleh estimasi yang bersifat BLUE maka dilakukan juga pengujian asumsi dasar.

\section{Hasil Estimasi Model Data Panel}

Analisis dampak trade creation dan trade diversion antara Indonesia dengan negara-negara anggota ASEAN-Korea menggunakan panel data statis pada gravity model dari tahun 1998-2012. Hasil uji chow menunjukkan bahwa Fixed Effect Model (FEM) lebih baik daripada Pooled Least Square (PLS), hal ini dilihat dari nilai statistik uji chow sebesar 48.90 (Prob $>\mathrm{F}=0.0000)$.

Uji Breusch Pagan LM memberikan hasil bahwa Random Effect Model (REM) lebih baik dari PLS dengan nilai statistik sebesar 706.98 (Prob $>$ chibar2 $=0.0000$ ).

Berdasarkan kedua pengujian tersebut, maka dilakukan uji hausman untuk menentukan model REM atau FEM yang akan digunakan pada penelitian ini. Hasil uji hausman menunjukkan bahwa REM lebih baik dari FEM dengan nilai statistik sebesar $4.79 \quad$ (Prob>Chi Square $=0.6854$ ) yang signifikan pada taraf nyata lima persen.
Uji Kelayakan dan Kecocokan Model (Goodness of fit)

Nilai probability (F-Statistic) yang ditunjukkan sebagai uji kelayakan model pada kedua subperiod yang digunakan adalah 0.0000 sehingga dapat disimpulkan bahwa minimal terdapat satu variabel bebas yang mempengaruhi variabel tidak bebas. Uji kecocokan model (goodness of fit) ditunjukkan pada nilai koefisien determinasi $\left(\mathrm{R}^{2}\right)$. Model menunjukkan nilai $\mathrm{R}^{2}$ sebesar 0.75 yang berarti variasi variabel bebas (PDB per kapita Indonesia, PDB per kapita Negara mitra dagang, jarak, nilai tukar riil, dummy bahasa, dummy trade creation, dummy trade diversion, dummy kebijakan) mampu menjelaskan $75 \%$ variasi variabel tidak bebas (impor), dan $25 \%$ dijelaskan oleh variabel lainnya.

\section{Uji Asumsi Dasar}

Uji asumsi dasar dilakukan untuk memperoleh estimasi yang bersifat BLUE (Best Linier Unbiased Estimator). Uji asumsi dasar ini meliputi uji multikolinearitas, heteroskedastisitas, dan autokorelasi. Uji multikolinearitas yang dilakukan pada model mengindikasikan adanya multikolinearitas yang ditunjukkan dengan adanya nilai korelasi antar variabel bebas dan tidak bebas bernilai lebih dari 0.75. Hal ini dapat dilihat pada Tabel 2 .

Uji heteroskedastisitas dilihat dari hasil Modified Wald Test sebagaimana Tabel 3.

Tabel 2 Uji Multikolinearitas

\begin{tabular}{|c|c|c|c|c|c|c|c|c|c|}
\hline & lnimpor & lnpdbk_i & lnpdbk_j & lnjarak & lnkurg & bahasa & im_ak & im_imu & dtahun \\
\hline Inimpor & 1.0000 & & & & & & & & \\
\hline lnpdbk_i & 0.2579 & 1.0000 & & & & & & & \\
\hline lnpdbk_j & 0.6823 & 0.2174 & 1.0000 & & & & & & \\
\hline lnjarak & -0.8141 & -0.0834 & -0.5391 & 1.0000 & & & & & \\
\hline lnkurs & 0.1494 & -0.0526 & -0.1327 & -0.3713 & 1.0000 & & & & \\
\hline bahasa & 0.2604 & -0.0000 & 0.2144 & -0.1106 & 0.1832 & 1.0000 & & & \\
\hline im_ak & 0.0520 & 0.6350 & -0.0005 & 0.1668 & -0.0996 & 0.1402 & 1.0000 & & \\
\hline im_imu & 0.4469 & 0.0633 & 0.4854 & -0.6350 & 0.1099 & -0.3015 & -0.2907 & 1.0000 & \\
\hline dtahun & 0.2255 & 0.8582 & 0.1953 & -0.0768 & -0.0362 & -0.0000 & 0.7192 & 0.0666 & 1.0000 \\
\hline
\end{tabular}


Tabel 3 Uji Heteroskedastisitas

\begin{tabular}{ll}
\hline Wald Test & Chi Square \\
\hline 0.0000 & 5052.78 \\
\hline
\end{tabular}

Dari Tabel ini, kita dapat melihat bahwa model mengalami heteroskedastisitas yang ditunjukkan dengan nilai wald test lebih kecil dari $\alpha$ (0.05).

Kemudian pada uji autokorelasi dapat dilihat dari hasil Wooldridge test seperti pada Tabel 4 .

Tabel 4 Uji Autokorelasi

\begin{tabular}{ll}
\hline F Stat & Probability \\
\hline 1.490 & 0.2457 \\
\hline
\end{tabular}

Menurut Tabel 4, model tidak mengandung autokorelasi yang ditunjukkan dengan nilai $\mathrm{F}$ Stat lebih besar dari $\alpha(0.05)$.

Untuk mengatasi masalah pada model, maka digunakan model panel data dengan General Least Square (GLS) untuk mengatasi pelanggaran asumsi tersebut.

\section{Trade Creation dan Trade Diversion antara Indonesia dengan Negara - negara ASEAN-Korea}

Trade creation dan trade diversion merupakan efek positif dan negatif dari pembentukan kerjasama FTA yang terjadi pada negara-negara anggota, yang dalam hal ini adalah ASEAN-Korea. Trade creation terjadi akibat beralihnya konsumsi dari produk domestik yang bersifat high-cost ke produk impor dari luar negeri yang bersifat low-cost (Viner 1950) sehingga terciptanya peningkatan perdagangan intra negara anggota. Sementara, perbedaan tarif yang diberlakukan untuk negara anggota dan negara non-anggota dalam suatu kawasan perdagangan bebas mengubah arah kecenderungan perdagangan hingga terjadi trade diversion yang merujuk pada perpindahan dari produk impor yang bersifat low-cost dari negara non-anggota dengan produk impor yang bersifat high-cost dari negara anggota dan terjadi penurunan perdagangan dengan negara non-anggota.

Variabel dummy trade creation dan dummy trade diversion digunakan sebagai variabel yang dapat menangkap dampak dari ASEAN-Korea FTA pada arus impor Indonesia. Berdasarkan hasil estimasi yang dilakukan dalam penelitian ini, dummy trade creation dan dummy trade diversion memberikan pengaruh yang signifikan terhadap arus impor Indonesia saat diberlakukannya FTA dengan taraf nyata satu persen. Nilai koefisien pada dummy trade creation bernilai 0.07 dan koefisien dummy trade diversion bernilai -1.14. Tanda positif pada dummy trade creation dan negatif pada dummy trade diversion mengindikasikan adanya trade diversion pada arus impor Indonesia.

Bila dilihat dari tanda koefisien dummy trade creation dan dummy trade diversion, maka perdagangan Indonesia tidak mengalami trade creation saat ASEAN-Korea FTA diberlakukan. Sementara, koefisien pada dummy trade diversion bernilai negatif yang mengindikasikan adanya pengalihan perdagangan Indonesia dari negara asal impor non-anggota ke negara asal impor anggota ASEAN-Korea. Indonesia akan melakukan perdagangan $68 \%$ $[(\exp (-1.14)-1) * 100]$ lebih sedikit dari tingkat perdagangan yang dilakukan Indonesia saat ini. Hal ini sejalan dengan penelitian yang dilakukan oleh Akhter dan Ghani (2010). Terjadinya trade diversion pada perdagangan impor Indonesia karena adanya penurunan tarif sebesar $<5 \%$ secara bertahap pada beberapa produk yang disepakati dalam ASEAN-Korea FTA yang juga diimpor dari dunia dan harga penawaran yang lebih rendah sehingga Indonesia lebih memilih untuk mengimpor produk-produk dari kawasan ASEAN-Korea dibandingkan dari negara pengekspor lainnya.

Selain dampak integrasi regional 
seperti trade creation dan trade diversion, hasil analisis menunjukkan bahwa impor Indonesia juga dipengaruhi oleh beberapa parameter, sebagaimana hasil estimasi yang ditunjukkan oleh Tabel 5 . Berdasarkan hasil estimasi tersebut dapat diketahui bahwa model mempunyai delapan variabel independen yang berpengaruh signifikan terhadap arus perdagangan impor pada taraf nyata satu persen, yaitu PDB per kapita negara
Indonesia menunjukkan kemampuan negara Indonesia dalam melakukan perdagangan dengan negara mitra dagang. Semakin besar kemampuan dan kapasitas suatu negara maka semakin besar perdagangan yang dilakukan dan berdampak pada peningkatan pendapatan per kapita.

\section{PDB per Kapita Negara Mitra Dagang}

Hasil estimasi pada variabel PDB

Tabel 5 Hasil estimasi koefisien parameter dengan GLS

\begin{tabular}{|c|c|c|c|}
\hline \multirow[t]{2}{*}{ Variabel Bebas } & \multicolumn{3}{|c|}{ Tahun 1998-2012 } \\
\hline & Koefisien & $\mathrm{z}$ & Prob. \\
\hline lnpdbk_i (PDB per Kapita Indonesia) & $0.60 * *$ & 39.48 & 0.000 \\
\hline lnpdbk_j (PDB per Kapita negara mitra dagang) & $0.56 * *$ & 70.33 & 0.000 \\
\hline lnjarak (jarak ekonomi) & $-1.22 * *$ & -79.69 & 0.000 \\
\hline lnkurs (nilai tukar riil) & $-0.09 * *$ & -12.87 & 0.000 \\
\hline $\begin{array}{l}\text { bahasa (dummy bahasa, nilai } 1 \text { jika bahasa yang } \\
\text { digunakan sama dan nilai } 0 \text { sebaliknya) }\end{array}$ & $0.78 * *$ & 24.46 & 0.000 \\
\hline $\begin{array}{l}\text { im_ak (dummy trade creation, nilai } 1 \text { jika } \\
\text { negaranya Indonesia \& negara ASEAN-Korea dan } \\
\text { nilai } 0 \text { sebaliknya) }\end{array}$ & $0.07 * *$ & 4.75 & 0.000 \\
\hline $\begin{array}{l}\text { im_imu (dummy trade diversion nilai } 1 \text { jika } \\
\text { negaranya Indonesia \& negara pengimpor utama }\end{array}$ & $-1.14 * *$ & -28.26 & 0.000 \\
\hline $\begin{array}{l}\text { Indonesia dan nilai } 0 \text { sebaliknya) } \\
\text { dkebijakan (dummy kebijakan, nilai } 1 \text { jika tahun } \\
\text { ke-t setelah pemberlakuan ASEAN-Korea FTA } \\
\text { dan nilai } 0 \text { sebaliknya) }\end{array}$ & $0.11 * *$ & 6.02 & 0.000 \\
\hline $\mathrm{C}$ (konstanta) & $13.52 * *$ & 69.72 & 0.000 \\
\hline
\end{tabular}

Keterangan:

1) Variabel tak bebas $=\ln I M$ (impor Indonesia dari negara mitra dagang)

2) ** menunjukkan tingkat signifikansi pada taraf $\alpha=1 \%$

Indonesia, PDB per kapita negara per kapita negara mitra dagang pengimpor, jarak ekonomi, nilai tukar riil, menunjukkan pengaruh yang positif dan dummy bahasa, dummy trade creation, signifikan sebesar 0.56. Hal ini berarti dummy trade diversion dan dummy bahwa peningkatan PDB per kapita negara kebijakan.

\section{PDB per Kapita Indonesia}

Peningkatan pendapatan per kapita Indonesia sebesar $1 \%$ akan meningkatkan impor sebesar $0.6 \%$, ceteris paribus. Hasil penelitian ini sejalan dengan temuan yang dilakukan oleh Robert (2010), Zidi dan Dhifallah (2013). Pendapatan per kapita mitra dagang sebesar $1 \%$ akan meningkatkan impor sebesar $0.56 \%$, ceteris paribus. Hasil penelitian ini sejalan dengan temuan yang dilakukan oleh Robert (2010). Tanda positif pada koefisien sesuai dengan hipotesis penelitian. Pendapatan per kapita negara mitra dagang menunjukkan daya beli konsumen, semakin tinggi daya beli 
masyarakat Indonesia maka impor Indonesia akan semakin besar.

\section{Jarak Ekonomi}

Biaya transportasi dalam penelitian ini diukur dengan nilai jarak ekonomi suatu negara. Jarak ekonomi merupakan salah satu syarat yang cukup penting pada gravity model dan besarnya jarak ekonomi akan mempengaruhi arus perdagangan impor secara negatif. Hasil estimasi yang diperoleh model menunjukkan bahwa variabel jarak berpengaruh signifikan terhadap impor dengan taraf nyata satu persen, besaran nilainya yaitu 1.22. Koefisien tersebut bernilai negatif sehingga sesuai dengan teori ataupun hipotesis pada penelitian ini.

Setiap peningkatan jarak ekonomi sebesar $1 \%$ antar kedua negara yang saling berdagang akan menurunkan arus perdagangan sebesar $1.22 \%$, ceteris paribus. Hasil penelitian ini sejalan dengan temuan yang dilakukan oleh Zidi dan Dhifallah (2013), serta Muhammad dan Yucer (2010). Hal ini menjelaskan bahwa koefisien jarak yang bernilai negatif mengindikasikan semakin besar jarak antar negara, maka perdagangan yang dilakukan akan semakin menurun.

\section{Nilai Tukar Riil}

Berdasarkan hasil estimasi, nilai tukar rupiah terhadap mata uang negara pengimpor memberikan pengaruh nyata terhadap impor sebesar 0.09. Koefisien yang bernilai negatif sesuai dengan teori dan hipotesis pada penelitian ini. Hal ini berarti bahwa setiap peningkatan nilai tukar riil sebesar $1 \%$ akan menurunkan nilai impor sebesar $0.09 \%$, ceteris paribus. Hasil penelitian ini, sejalan dengan temuan yang dilakukan oleh Kemal dan Qadir (2005). Hal tersebut mengimplikasikan bahwa depresiasi pada nilai tukar riil dapat menaikkan harga impor di dalam negeri sehingga dapat mengurangi permintaan impor di dalam negeri, dan sebaliknya.

\section{Dummy Bahasa}

Variabel dummy bahasa digunakan dalam penelitian ini sebagai salah satu variabel yang merupakan variabel standar pada gravity bilateral yang dapat mengukur dampak dari ASEAN-Korea FTA. Variabel dummy bahasa memberikan pengaruh signifikan terhadap impor yang dapat dilihat dari nilai koefisien sebesar 0.78. Nilai koefisien tersebut mengindikasikan adanya perbedaan nilai impor sebesar $118 \%$ $[(\exp (0.78)-1) * 100]$ lebih tinggi jika kedua negara menggunakan bahasa yang sama dalam melakukan perdagangan dibandingkan tidak menggunakan bahasa yang sama.

\section{Dummy Kebijakan}

Variabel dummy kebijakan pada penelitian ini digunakan untuk menangkap perbedaan tahun saat sebelum dan sesudah ASEAN-Korea FTA diberlakukan untuk tiap tahunnya. Hasil estimasi menunjukkan bahwa dummy kebijakan berpengaruh nyata dan bertanda positif terhadap arus perdagangan dengan besaran nilai koefisien 0.11. Hal tersebut berarti dummy kebijakan mampu memperlihatkan perbedaan nilai impor sebesar $11 \%$ $\left[(\exp (0.11)-1)^{*} 100\right]$ lebih tinggi bila perdagangan terjadi setelah ASEAN-Korea FTA diberlakukan.

\section{SIMPULAN DAN SARAN}

\section{Simpulan}

Hasil estimasi pada penelitian ini menunjukkan bahwa sektor perdagangan Indonesia tidak mengalami trade creation, tetapi terjadi trade diversion pada saat ASEAN-Korea FTA diberlakukan. Trade diversion terjadi karena penurunan tarif secara bertahap dari negara anggota ASEAN-Korea dan adanya harga 
penawaran yang lebih rendah. Hal ini dapat dilihat dari arus perdagangan Indonesia dengan negara non-anggota sebesar $68 \%$ lebih sedikit dari tingkat perdagangan yang saat ini dilakukan dengan negara non-anggota. Secara keseluruhan, Indonesia mengalami kerugian akibat terjadinya trade diversion yang berdampak pada pengurangan pendapatan pemerintah dan kesejahteraan nasional yang didapat dari pengenaan tarif yang berasal dari negara-negara diluar kawasan ASEAN-Korea.

Berdasarkan hasil penelitian, arus perdagangan impor Indonesia mengalami peningkatan ketika perjanjian perdagangan barang dalam ASEAN-Korea FTA diberlakukan sebagai dampak dari integrasi regional. PDB per kapita negara Indonesia, PDB per kapita negara mitra dagang, jarak ekonomi, nilai tukar riil, dummy bahasa, dummy trade creation, dummy trade diversion dan dummy kebijakan merupakan faktor yang dapat mempengaruhi perdagangan impor Indonesia saat ASEAN-Korea FTA telah diberlakukan.

\section{Saran}

Berdasarkan hasil penelitian yang diperoleh, ada beberapa hal yang dapat disarankan:

1. Mengingat variabel nilai tukar riil berpengaruh signifikan, maka pemerintah dapat mempengaruhi nilai tukar riil sebagai langkah untuk meningkatkan nilai perdagangan dengan cara menurunkan nilai tukar riil terhadap mata uang negara mitra dagang.

2. Trade diversion yang terjadi pada sektor perdagangan dapat mempengaruhi pendapatan pemerintah dan kesejahteraan nasional menjadi berkurang. Untuk mengatasi hal ini, pemerintah perlu bernegosiasi dengan negara mitra dagang non-anggota kawasan untuk memberikan harga penawaran yang lebih rendah atau mendekati harga penawaran dari negara anggota kawasan sehingga kesejahteraan nasional akan meningkat.

3. Agar terjadi trade creation dalam kawasan ASEAN-Korea, pemerintah dapat meningkatkan ekspor dan impor produk-produk yang telah mendapatkan penurunan tarif dengan negara anggota dengan cara membuka akses pasar untuk produk-produk baru.

\section{DAFTAR PUSTAKA}

Agbodji AE. 2008. The Impact of Subregional Integration on Bilateral Trade: The case of UEMOA. AERC Research Paper 186. African Economic Research Consortium, Nairobi.

Akhter N, Ghani E. 2010. Regional Integration in South Asia: An Analysis of Trade Flows Using the Gravity Model. The Pakistan Development Review, Vol. 49 Issue 2, pp 105-118.

ASEAN. 2013. ASEAN Community in Figures 2012 (ACIF 2012). Jakarta.

ASEANstats. 2013. ASEAN Statistical Publication. www.asean.org/aseanstats. [diakses 10 Oktober 2013]

Clausing KA. 2001. Trade Creation and Trade Diversion in the Canada-United States Free Trade Agreement. The Canadian Journal of Economics, Vol. 34, No.3. Wiley on behalf of the Canadian Economics Association.

Departemen Perdagangan. 2010. Mепијu ASEAN ECONOMIC COMMUNITY 2015. Jakarta : Direktorat Jenderal Kerjasama Perdagangan Internasional.

Firdaus M. 2011. Aplikasi Ekonometrika untuk Data Panel dan Time Series. Bogor : IPB Press.

Gujarati D. 2004. Basic Econometrics, $4^{\text {th }}$ Edition. The McGraw-Hill Companies. 
Jin HJ, Koo WW, Sul B. 2006. The Effects of The Free Trade Agreement Among China, Japan, and South Korea. Journal of Economic Development, Vol. 31, No. 2.

Kemal MA, Qadir U. 2005. Real Exchange Rate, Exports, and Imports Movements: A Trivariate Analysis. The Pakistan Development Review. Pakistan.

Kementerian Perdagangan. 2013. ASEAN-KOREA FREE TRADE AREA [internet]. [diunduh 2013 Oktober 24]. Tersedia pada: http://ditjenkpi.kemendag.go.id/website _kpi/Website_tr/Preferential\%20Tariff/ ASEAN-KOREA/ASEAN\%20-\%20K orea\%20FTA.pdf

Muhammad K, Yucer A. 2010. Impact of Regional Trade Agreements: Trade Creation and Trade Diversion in Western Hemisphere. International Journal of Economics Issues, Vol. 3, No. 2, p. 221-238.

Roberts B. 2004. A Gravity Study of the Proposed China-ASEAN Free Trade Area. The International Trade Journal, Vol. 18 Issue 4 pages 335-353. Taylor $\&$ Francis.

Salvatore D. 1997. International Economics. New Jersey: Prentice HallGale.

Susanto D, Rosson CP, Adcock FJ. 2007. Trade Creation and Trade Diversion in the North American Free Trade Agreement: The Case of the Agricultural Sector. Journal of Agricultural and Applied Economics Vol. 39 Issue 01. Southern Agricultural Economic Association.

Viner J. 1950. The Customs Union Issue. New York: Stevens \& Sons Ltd.

[WTO] World Trade Organization. 2013. Annual Report 2013. Geneva, Switzerland. . 2013.

World Trade Report 2013 : Factors Shaping the Future of World Trade. Geneva, Switzerland.
Yang S, Martinez-Zarzoso I. 2013. A Panel Data Analysis of Trade Creation and Trade Diversion Effects : The case of ASEAN-China Free Trade Area (FTA). Discussion Paper for Economic Research. Germany : Faculty of Economic Sciences, University of Goettingen.

Yin X. 2004. The Impact of The China-ASEAN Free Trade Agreement on Regional Trade. The Journal of East Asian Affairs, Vol. 18, No. 2 (Fall/Winter 2004), pp. 311-339.

Zidi A, Dhifallah SM. 2013. Trade Creation and Trade Diversion between Tunisia and EU: Analysis by Gravity Model. International Journal Economics and Finance, Vol. 5, No.5 pages 131-147. Canadian Center of Science and Education. 